\title{
MALIGNANT CHANGE IN AN INTRACRANIAL EPIDERMOID
}

\author{
BY
}

\section{S. I. DAVIDSON and J. M. SMALL}

From the Midland Centre for Neurosurgery, Smethwick

Intracranial epidermoids are rare tumours, their incidence being about $0.5 \%$. They are of congenital origin arising from epithelial rests, usually in relation to neural crest derivative structures (von Remak, 1854; Bostroem, 1897; Critchley and Ferguson, 1928). They are almost always benign, slowly-growing tumours containing structureless kerato-hyaline material bounded by a capsule consisting of a thin layer of squamous epithelium without dermal elements, in some areas, and a false capsule in others.

Malignant change in the epithelial lining of these tumours is rare, and only five reports have been found in the literature. Stromeyer's (1910) case has been cited as the earliest example of malignant change reported in an intracranial epidermoid (Tytus and Pennybacker, 1956), but there is considerable doubt as to the carcinomatous nature of the malignant tissue, and indeed if it was neoplastic at all (Zülch, 1956). Henschen (1955) was probably more correct in assuming that the tumour was a combination of epidermoid and glioblastoma, and mentions having seen one other such case. Ernst (1912) reported a case of a 52-year-old man with symptoms of an angle syndrome for eight years. Post-mortem examination revealed an epidermoid in the right cerebello-pontine angle which had undergone malignant change, infiltrating the pons, cerebellum, ventricle, and the meninges. It was said to be a non-keratinizing, squamous-cell carcinoma. Hug's case (1942) was in a 49-year-old man who had had symptoms for 13 years, and at necropsy a parapontine epidermoid was found in direct connexion with a squamous-cell carcinoma which was occupying the left temporal lobe. A case of Kahn's (1956) was mentioned without details by Zülch (1956), and this was apparently a non-keratinizing, squamous-cell carcinoma. Henkel (1952) reported two further cases of carcinomatous change in epidermoids. They were both in males aged 49 and 76 , and both were parapontine in position.

The case being reported is in a man aged 46 , who had complained of frontal headache for some five months. Seven weeks before admission to hospital he had had a generalized epileptiform attack. He also complained of poor vision in the right eye, but did not give a consistent account of the duration of this symptom.

He was a restless, rather drowsy man with a poor memory, and indulging in facile behaviour. The only abnormal neurological finding apart from this was the absence of reaction to light of the right pupil except consensually; the visual acuity in the right eye was perception of bright light only, whilst in the left eye the visual acuity was J.4 and the field of vision full. There was papilloedema in the left fundus, whilst on the right there was primary optic atrophy; the tone in the right limbs was slightly increased as judged by the tendon reflexes.

All ancillary investigations were normal except for the radiological changes in the skull which showed a smalle area of calcification in the right subfrontal area. Carotid angiography revealed the presence of a right fronto-polare space-occupying lesion (Fig. 1). The cerebrospinal fluido was not examined.

Operative exploration was carried out by a right frontal osteoplastic bone flap. When the dura was opened a brain needle was passed into the right frontal lobe and encountered resistance at about $2 \mathrm{~cm}$. depth. The needle? was then passed on into the resistance, and when the stillette was removed a little turbid fluid escaped. An incision was made into the right frontal lobe to expose the surface of an obvious tumour $2 \mathrm{~cm}$. from the cortical surface. As soon as this was entered it was clear that it was an epidermoid containing the typical tissue. A larger area of frontal cortex was then removed to obtain adequate access for removal of the interior of the epidermoid. After a considerable amount of the interior of this tumour had been removed a subfrontal exploration showed that at the base the epidermoid was insinuating itself between the right optic nerve and carotid artery. The right optic nerve was very swollen, whereas the left optic nerve was normal. The whole of the interior of the epidermoid was removed from a cavity about 6 to $7 \mathrm{~cm}$. in diameter, and from projections passing out between the branches of the anterior cerebral artery and around the middle cerebral artery. Much of the capsule was also removed. The whole of the swollen right optic nerve was resected.

Histological examination of a part of the cyst wall showed it to be lined by epidermis with well-marked keratin formation (Fig. 2). The right optic nerve showed gliosis with a few calcospherites, focal areas of lymphocytic infiltration, and invasion by a moderately well- 
differentiated epidermoid carcinoma with numerous mitoses. Cell rests were seen but did not show keratin formation (Figs. 3 and 4).

The patient made a satisfactory recovery from his operation, and after some deep $x$-ray treatment to the area of the right optic foramen he returned to work.

It is interesting to note that the first description of the syndrome of unilateral optic atrophy and contralateral papilloedema, which this patient showed, often attributed to Foster Kennedy (1911), had already been described by Schultz-Zehden (1905) six years previously, in a case of an epidermoid tumour apparently arising in the region of the chiasmatic cistern and invading the right lateral ventricle. This tumour had compressed, but not infiltrated, the right optic nerve. The nerve was surrounded by tumour up to the optic foramen. It may be more appropriate to classify this tumour of SchultzZehden as a basal rather than a frontal epidermoid, as has been done previously by Jefferson (1945) and Duke-Elder (1949). From our experience it would appear that truly intrinsic epidermoid tumours of the brain do not occur, but insinuate themselves into an apparent intrinsic position.

The historical aspects of the Foster Kennedy syndrome have been amply reviewed by Jefferson (1945), but it would not be inappropriate to mention a few clinical facts not generally appreciated. The syndrome is rare (Sachs, 1927; Lillie, 1927; Hyland and Botterell, 1937; Henderson, 1938; Jefferson, 1945), and is more common in sphenoidal wing meningiomata than in frontal lobe or olfactory groove tumours (Cushing and Eisenhardt, 1938). Kearns and Wagener (1953) have pointed out that the Foster Kennedy syndrome in the absence of any abnormality of the sense of smell is suggestive of a sphenoidal wing meningioma. Finally, the side of the optic atrophy is not invariably the side of the tumour (David and Sourdille, 1942; Jefferson, 1945; Ford, 1957; Walsh, 1957).

\section{Summary}

A case of carcinomatous change occurring in a right frontal epidermoid in a 46-year-old man is described. The malignant tissue had infiltrated the right optic nerve and produced a Schultz-Zehden syndrome.

Our thanks are due to Dr. C. P. Moxon and Dr. A. L. Woolf for the radiological and pathological reports.

\section{REFERENCES}

Bostroem, E. (1897). Zbl. allg. Path. path. Anat., 8, 1.

Critchley, M., and Ferguson, F. R. (1928). Brain, 51, 334.

Cushing, H., and Eisenhardt, L. (1938). Meningiomas, p. 298 Thomas, Springfield, Illinois.

David, M., and Sourdille, G. (1942). J. Ophtal., 1, 215. Cited by F. B. Walsh (1957).

Duke-Elder, W. S. (1949). Textbook of Ophthalmology, Vol. 4, p. 3482. Kimpton, London.

Ernst, P. (1912). Verh. dtsch. path. Ges., 15, 226

Ford, F. R. (1957). Cited by F. B. Walsh. In Clinical Neuro-Ophthalmology, 2nd ed., p. 994. Williams and Wilkins, Baltimore.

Henderson, W. R. (1938). Brit. J. Surg., 26, 124

Henkel, H. G. (1952). Verh. dtsch. Ges. Path., 1951, 35, 185.

Henkel, H. G. (1952). Verh. dtsch. Ges. Path., 1951, 35, 185. Anatomie und Histologie, band 13, teil 3, p. 648. Edited by $O$. Lubarsch, F. Henke, and R. Rössle. Springer, Berlin.

Hug, O. (1942). Virchows Arch. path. Anat., 308, 679.

Hyland, H. H., and Botterell, E. H. (1937). Canad. med. Ass. J., 37, 530 .

Jefferson, G. (1945). Trans. ophthal. Soc. U.K., 65, 262.

Kahn, E.(1956). Cited by K. J. Zulch in Handbuch der Neurochiruogie Vol. 3, p. 551, Edited by H. Olivecrona and W. Tönnis. Springer, Berlin.

Kearns, T. P., and Wagener, H. P. (1953). Amer. J. med. Sci., 226, 22i.

Kennedy, F. (1911). Ibid., 142, 355.

Lillie, W. I. (1927). J. Amer. med. Ass., 89, 2099.

Remak, $\mathbf{R}$. von (1854). Cited by Critchley and Ferguson.

Sachs, E. (1927). Brain, 50, 474.

Schultz-Zehden (1905). Klin. Mbl. Augenheilk, 43 (2), 193.

Stromeyer, F. (1910). Beitr. path. Anat., 47, 392.

Tytus, J. S., and Pennybacker, J. (1956). J. Neurol. Neurosurg. Psychiat., 19, 241.

Walsh, F. B. (1957). Clinical Neuro-Ophthalmology, 2nd ed., p. 32 Williams and Wilkins, Baltimore.

Zülch, K. J. (1956). In Handbuch der Neurochirugie, Vol 3, p. 551 Edited by $\mathbf{H}$. Olivecrona and W. Tönnis. Springer, Berlin. 